Marta Fichna1, 2, Izabela Krzyśko-Pieczka³, Magdalena Żurawek², Bogda Skowrońska ${ }^{3}$, Anna Gertig-Kolasa ${ }^{3}$, Piotr Fichna ${ }^{3}$

${ }^{1}$ Department of Endocrinology, Metabolism and Internal Medicine, Poznan University of Medical Sciences, Poznan

${ }^{2}$ Institute of Human Genetics, Polish Academy of Sciences, Poznan

${ }^{3}$ Department of Paediatric Diabetes and Obesity, Poznan University of Medical Sciences, Poznan

\title{
Lack of association of the HSD11B1 gene polymorphisms with obesity and other traits of metabolic syndrome in children and adolescents
}

\section{ABSTRACT}

Introduction. Obesity and its related disorders, clustered into metabolic syndrome (MetS), are increasingly diagnosed in children and adolescents. Clinical features, which define MetS are also encountered in patients with glucocorticoid excess. Since no evident hypercortisolaemia was detected in obesity and MetS, investigations turned to the local modulators of cortisol action. 11 $\beta$-hydroxysteroid dehydrogenase type 1 , encoded by HSD11B1 gene, controls tissue availability of cortisol by its regeneration from inert cortisone. Changes in HSD11B1 expression and enzyme activity may be influenced by its sequence variants and seem implicated in MetS pathogenesis. Our study was designed to evaluate plausible association of the HSD11B1 polymorphisms with early-onset obesity and features of MetS in Polish children and adolescents. Material and methods. The study comprised of 258 obese children (136 females), aged $12.3 \pm 3.6$ years,

Address for correspondence:

dr hab. n. med. Marta Fichna

Katedra i Klinika Endokrynologii, Przemiany Materii

i Chorób Wewnętrznych

Uniwersytet Medyczny im. K. Marcinkowskiego

ul. Przybyszewskiego 49, 60-355 Poznań

Phone: +48618691330

Fax: +48 8691682

e-mail: mfichna@man.poznan.pl

Clinical Diabetology 2016, 5, 6, 178-184

DOI: $10.5603 /$ DK.2016.0031

Received: 25.08.2016 Accepted: 07.03.2017 with excessive body mass lasting $7.1 \pm 3.8$ years. Anthropometric and blood pressure measurements, baseline biochemical analyses and oral glucose tolerance test were performed in all participants. Genotyping of the HSD11B1 variants rs12086634, rs846910, rs4844880, and rs3753519 was conducted in obese youth and compared with 568 lean blood donors.

Results. Mean relative body mass index in obese cohort was $164.7 \pm 27.1 \%$. Hypertension was detected in $\mathbf{1 2 . 4 \%}$, impaired fasting glucose in $8.9 \%$, impaired glucose tolerance in $10.8 \%$, diabetes in $2.7 \%$, and dyslipidemia in $31.4 \%$ children and adolescents. None of the studied HSD11B1 polymorphisms displayed significant difference in frequency between obese and lean individuals. MetS was diagnosed in $27.6 \%$ of 203 patients with obesity aged $10-18$ years. Further genotype-stratified analyses of relationship between HSD11B1 variants and particular features of MetS did not confirm increased susceptibility to develop early-onset hyperglycaemia, dyslipidaemia and hypertension in carriers of specific genotypes at rs4844880, rs846910, rs3753519, and rs12086634 ( $p \geq 0.05$ in all tests).

Conclusion. Our study does not support the implication of the HSD11B1 polymorphisms in early-onset obesity and other features of MetS. (Clin Diabetol 2016; 5, 6: 178-184)

Key words: childhood obesity, HSD11B1 gene, polymorphism, cortisol, metabolic syndrome 


\section{Introduction}

Obesity is a soaring healthcare problem in modern societies. It increasingly affects the youngest populations and leads to a number of complications, which subsequently contribute to higher morbidity and mortality [1]. Metabolic syndrome (MetS) is a cluster of obesity-related traits associated with an elevated risk of type 2 diabetes (T2D) and cardiovascular disease [2]. Individuals who develop MetS in childhood have a doubled or tripled future risk of atherosclerosis and diabetes compared to those with no MetS at youth [1]. Of note, typical features, which define MetS are equally encountered in patients suffering from glucocorticoid excess, i.e. Cushing's syndrome, either of endogenous or exogenous origin $[3,4]$. These clinical observations prompted detailed studies of the hypothalamo-pituitary-adrenal (HPA) axis in patients with obesity and MetS. However, despite some indices of the enhanced HPA reactivity to physiologic and pharmacologic stimuli, consistently elevated cortisol levels were not confirmed in obese individuals [5].

Identification of enzymes, which exert modulatory role on cortisol action in tissues, paved the way for new hypotheses on glucocorticoid role in cardiometabolic disorders. 11 $\beta$-hydroxysteroid dehydrogenase type 1 $(11 \beta$-HSD1) primarily acts as a ketoreductase and controls local availability of cortisol by its NADPH-dependent regeneration from the inert cortisone [6]. The enzyme, encoded by the HSD11B1 gene, is widely expressed in the liver, adipose tissue, muscle and central nervous system, where it amplifies glucocorticoid action [7]. Variable degree of $11 \beta$-HSD1 activity may account for enhanced or attenuated local glucocorticoid effects. Transgenic mice with selective overexpression of $11 \beta$-HSD1 in their adipose tissue display features of MetS - visceral obesity, insulin resistance and hyperlipidaemia [8]. On the contrary, mice with targeted enzyme knockout or its selective inhibition seem protected from the adverse effects of the high-fat diet $[9,10]$. In humans, increased expression of $11 \beta$ -HSD1 was confirmed in visceral adipose tissue of obese, insulin resistant individuals [11]. A positive correlation between body mass index (BMI) and HSD11B1 mRNA in adipose tissue was noted [11, 12]. Women with the highest enzyme activity in their visceral adipose tissue presented enhanced lipolysis and insulin resistance indexes, together with the lowest HDL cholesterol and adiponectin levels [13].

Therefore, early development of MetS might be connected with an altered HSD11B1 gene expression and enzyme activity. As indicated in vitro and confirmed by in vivo studies, transcriptional activity and subsequent $11 \beta$-HSD1 expression may be affected by single nucleotide polymorphisms (SNPs) in the HSD11B1 gene [14-17]. Rs846910 and rs 12086634 appeared to be significantly associated with T2D in Pima Indians and with glucose uptake in the euglycaemic-hyperinsulinaemic clamp, although no direct association with BMI was found [18]. A Korean study revealed plausible association of the HSD11B1 polymorphisms with MetS, fasting plasma glucose and BMI [19]. In European populations, a relationship of rs846910 and rs 12086634 with the risk of MetS was described in Italian women [15]. Moreover, an association of the latter variant with an elevated HSD11B1 mRNA in subcutaneous adipose tissue and enhanced conversion of cortisone to cortisol assessed in $24 \mathrm{~h}$ urine collections were reported [15]. In Spanish children rs3753519 appeared to be associated with obesity, although no effect on glucose balance was detected [20]. In a small American study an association between an adenine insertion in HSD11B1 gene intron 3 (ins4436A, rs45487298) and increased $\mathrm{BMI}$, waist-to-hip ratio and insulin resistance indices in children was found [21]. More recent analysis in young Mexican-Americans confirmed that rs 846910 was associated with Homeostatic Model Assessment of Insulin Resistance (HOMA-IR) and circulating triglycerides but not with obesity [22]. Finally, a Chinese study linked several HSD11B1 variants with childhood obesity and its cardiometabolic complications - hypertension, hypercholestarolaemia, and hyperglycaemia [23]. On the contrary, a study conducted among the elderly Dutch, revealed no association of HSD11B1 gene with body composition and glucose metabolism [24]. However, plausible influence of genetic factors is rather expected to be more prominent in early-onset disorders. Baring this in mind, the current study was designed to evaluate plausible association of the HSD11B1 polymorphisms with early-onset obesity and other features of the metabolic syndrome among Polish children and adolescents.

\section{Material and methods}

Two hundred fifty eight unrelated children (136 females, 122 males) referred to the Department of Paediatric Diabetes and Obesity at Poznan University of Medical Sciences for the reason of obesity, were enrolled. Their mean age \pm standard deviation $( \pm S D$ ) was $12.3 \pm 3.6$ years and mean duration of excessive body mass was $7.1 \pm 3.8$ years. Their pubertal development evaluated according to the Tanner scale was stage 1 in $22.4 \%$, stage 2 in $19.4 \%$, stage 3 in $14.7 \%$, stage 4 in $17.4 \%$ and stage 5 in $26.0 \%$ individuals. Children suffering from the endocrine-related, medication-induced or syndromic obesity were excluded from the study. Informed consent was obtained from parents of the minor patients and additionally from participants 
above 16 years old. Local ethical committee at Poznan University of Medical Sciences has approved the study protocol (decision 233/13) and all procedures were in accordance with the Declaration of Helsinki.

Control samples for genotyping were obtained from 568 healthy lean blood donors recruited at the Regional Blood Transfusion Centre. Their mean age was $38.1 \pm 10.2$ years and mean BMI was $23.6 \pm 1.3 \mathrm{~kg} / \mathrm{m}^{2}$

Clinical evaluation of obese patients comprised their weight and height measurement with calibrated stable stadiometer and electronic scales. BMI was calculated as weight $[\mathrm{kg}] /$ height $\left[\mathrm{m}^{2}\right]$. For the purpose of this study, obesity was defined as BMI-for-age value $\geq 95^{\text {th }}$ percentile (i.e. BMI standard deviation score $>2$ ) according to the Polish growth charts [25]. Relative body mass index (RBMI) was calculated as proportion of individual BMI vs. mean BMI at the $50^{\text {th }}$ percentile for age and gender [26]. Additionally waist circumference (WC) was measured in all patients and referred to the Polish percentile charts for children and adolescents [27]. Blood pressure (BP) measurements were taken between 9 a.m. and 11 a.m. on three consecutive days, in a seated position after 10 min rest, using a validated oscillometric sphygmomanometer with a suitable cuff size. Hypertension was defined as mean value of three measurements exceeding $95^{\text {th }}$ percentile for gender and age [28].

Biochemical analyses required morning blood sampling after overnight fast. Additionally, all patients underwent standard 2-hour oral glucose tolerance test (OGTT) with $1.75 \mathrm{~g}$ of glucose/kg (max. $75 \mathrm{~g}$ ) and evaluation of glycaemia and insulinaemia. Biochemical analyses including glucose, total cholesterol, HDL cholesterol, and triglycerides were performed by standard enzymatic methods with Olympus AU680 automated chemistry analyzer (Beckman Coulter Inc, Miami, FL, USA). Serum insulin was determined by immunochemiluminescence (Architect System, Santa Clara, USA).

Disorders of glucose tolerance were defined based upon guidelines of the International Society for Paediatric and Adolescent Diabetes (ISPAD) [29]. HOMA-IR was calculated as fasting serum insulin $(\mathrm{mU} / \mathrm{L}) \times$ fasting serum glucose ( $\mathrm{mmol} / \mathrm{L}) / 22.5$. Low-density lipoprotein (LDL) cholesterol was determined by Friedewald's formula. MetS was defined according to the International Diabetes Federation (IDF) consensus criteria for children and adolescents in subjects aged 10-15 years old and standard criteria for adults in individuals aged 16 and more years $[2,30]$.

\section{Genotyping}

Genomic DNA was extracted from the peripheral blood using Gentra Puregene Blood Kit (Qiagen,
Hilden, Germany). Genotyping of the HSD11B1 gene SNPs: rs4844880, rs846910, rs3753519, and rs12086634, was carried out by allelic discrimination analysis using the $7900 \mathrm{HT}$ Real-Time PCR System and validated commercial TaqMan SNP Genotyping assays (C_2502442 10, C_8887157_10, C_27474627_10, and C_22275 467 10, respectively) following the conditions recommended by the manufacturer (Applied Biosystems, Foster City, CA). Data acquisition and analysis were performed using the allelic discrimination analysis module in SDS v. 2.3 software (Applied Biosystems). The genotypes were confirmed in $8 \%$ samples by direct DNA sequencing with BigDye Terminator Cycle Sequencing Ready Reaction Kit (ABI Prism 3730 Genetic Analyzer, Foster City, CA). The samples of confirmed genotypes were run as controls in all reactions and $10 \%$ samples were re-genotyped blind to ensure accuracy.

\section{Statistical analysis}

Statistical analyses were performed by means of GraphPad Prism 6.0c (GraphPad Software, La Jolla, CA). Quantitative data are presented as mean $\pm S D$, median and interquartile range, while categorical data - as percentage. Hardy-Weinberg equilibrium of the genotyped SNPs was tested using online calculator devised at Tufts University (Medford, MA). Data normality was checked with Shapiro-Wilk test. Considering the low frequency of homozygotes for the minor alleles of the studied SNPs, these subjects were merged for statistical purposes with the heterozygotes and this group was compared with the homozygotes for the common wild-type allele. Normally distributed genotype-stratified data were subsequently compared using t-student test for unpaired samples, whereas those with non-normal distribution were analysed by nonparametric Mann-Whitney test. Two-tailed $p$-values $<0.05$ were considered statistically significant. Assuming odds ratio (OR) of 1.5 at a 0.05 level of significance, the power of this study to detect an effect was calculated based on PS Power and Sample Size calculator v. 2.1.30 (Vanderbilt University, Nashville, TN).

\section{Results}

Mean RBMI in the studied cohort was equal to $164.7 \pm 27.1 \%$. Hypertension was detected in 32 (12.4\%) obese individuals. Based upon the OGTT results, normal glucose tolerance was found in 200 (77.5\%) subjects, impaired fasting glucose - in 23 (8.9\%), impaired glucose tolerance - in 28 (10.8\%) and diabetes - in 7 (2.7\%) children and adolescents. Mean HOMA-IR value exceeded 3.0, indicating widespread insulin resistance in this cohort. Dyslipidemia defined according to the IDF criteria of MetS was detected in 
Table 1. Clinical and biochemical characteristics of the studied cohort of obese children and adolescents

\begin{tabular}{lcccc}
\hline & Mean & SD & Median & IQR \\
\hline RBMI (\%) & 164.7 & 27.1 & 160.0 & $144.4-179.3$ \\
SBP [mm Hg] & 114 & 3 & 108 & $105-117$ \\
DBP [mm Hg] & 71 & 2 & 67 & $64-76$ \\
Fasting glucose [mmol/L] & 4.95 & 0.52 & 4.89 & $4.67-5.18$ \\
Fasting insulin [mU/L] & 16.0 & 9.3 & 13.9 & $9.7-20.3$ \\
Glucose 2 h OGTT [mmol/L] & 6.54 & 1.40 & 6.39 & $5.72-7.22$ \\
Insulin 2 h OGTT [mU/L] & 77.7 & 61.8 & 57.8 & $36.6-101.5$ \\
HOMA-IR [mmol/L × mU/L] & 3.56 & 2.16 & 3.06 & $2.00-4.34$ \\
Triglycerides [mmol/L] & 1.39 & 0.77 & 1.16 & $0.92-1.64$ \\
Total cholesterol [mmol/L] & 4.65 & 0.84 & 4.69 & $4.09-5.21$ \\
HDL cholesterol [mmol/L] & 1.15 & 0.26 & 1.14 & $0.96-1.32$ \\
LDL cholesterol [mmol/L] & 2.84 & 0.69 & 2.77 & $2.38-3.29$ \\
\hline
\end{tabular}

RBMI - relative body mass index; SBP — systolic blood pressure; DPB - diastolic blood pressure; OGTT - oral glucose tolerance test; HOMA-IR - Homeostatic Model Assessment of Insulin Resistance; HDL — high-density lipoprotein; LDL — low-density lipoprotein; SD — standard deviation; IQR — interquartile range

Table 2. Distribution of alleles and genotypes of the HSD11B1 gene single nucleotide polymorphisms (SNPs) in 258 children and adolescents with obesity (OB) compared to 568 lean controls (CON)

\begin{tabular}{|c|c|c|c|c|c|c|}
\hline \multirow{2}{*}{$\begin{array}{l}\text { SNP } \\
\text { rs4844880 }\end{array}$} & \multirow[t]{2}{*}{ Cohort } & \multicolumn{2}{|c|}{ Genotypes (\%) } & \multirow[b]{2}{*}{ AA } & \multicolumn{2}{|c|}{ Alleles (\%) } \\
\hline & & TT & TA & & $T$ & $A$ \\
\hline & $\mathrm{OB}$ & $166(64.3)$ & $83(32.2)$ & $9(3.5)$ & 415 (80.4) & $101(19.6)$ \\
\hline & CON & $385(67.8)$ & $157(27.6)$ & $26(4.6)$ & 927 (81.6) & 209 (18.4) \\
\hline & $\mathrm{p}$ & \multicolumn{3}{|c|}{0.356} & \multicolumn{2}{|c|}{0.571} \\
\hline \multirow[t]{4}{*}{ rs846910 } & & GG & GA & AA & G & A \\
\hline & $\mathrm{OB}$ & $222(86.0)$ & $34(13.2)$ & $2(0.8)$ & $478(92.6)$ & $38(7.4)$ \\
\hline & CON & $508(89.4)$ & $59(10.4)$ & $1(0.2)$ & 1075 (94.6) & $61(5.4)$ \\
\hline & $\mathrm{p}$ & \multicolumn{3}{|c|}{0.201} & \multicolumn{2}{|c|}{0.113} \\
\hline \multirow[t]{4}{*}{ rs3753519 } & & GG & GA & AA & G & A \\
\hline & $\mathrm{OB}$ & $191(74.0)$ & $61(23.7)$ & $6(2.3)$ & $443(85.9)$ & $73(14.1)$ \\
\hline & CON & $438(77.1)$ & $124(21.8)$ & $6(1.1)$ & $1000(88.0)$ & $136(12.0)$ \\
\hline & $\mathrm{p}$ & \multicolumn{3}{|c|}{0.294} & \multicolumn{2}{|c|}{0.218} \\
\hline \multirow[t]{4}{*}{ rs12086634 } & & GG & GT & TT & G & $T$ \\
\hline & $\mathrm{OB}$ & $163(63.2)$ & 85 (32.9) & $10(3.9)$ & $411(79.7)$ & $105(20.3)$ \\
\hline & CON & $317(55.8)$ & $222(39.1)$ & $29(5.1)$ & $856(75.4)$ & $280(24.6)$ \\
\hline & $\mathrm{p}$ & \multicolumn{3}{|c|}{0.134} & \multicolumn{2}{|c|}{0.055} \\
\hline
\end{tabular}

$81(31.4 \%)$ individuals. Detailed biochemical analyses of the studied cohort are displayed in Table 1.

The frequencies of all investigated polymorphisms remained in Hardy-Weinberg equilibrium in patients and controls ( $p$-values $\geq 0.058$ ). Unfortunately, none of the four studied variants of the HSD11B1 gene displayed significant difference in genotype and allele distribution between obese and lean individuals (Tab. 2).

Since diagnosing the metabolic syndrome is only recommended in children aged at least 10 years old, we reviewed the results of this subgroup of patients with regard to the IDF consensus criteria. The diagnosis of MetS was established in 56 (27.6\%) out of 203 individuals aged 10-18 years old. Only this cohort was further studied in genotype-stratified analyses aiming to detect a relationship between HSD11B1 gene polymorphisms and features of MetS. However, as presented in Table 3, these calculations did not confirm that carriers of specific genotypes of rs4844880, rs846910, rs3753519, and rs12086634 might be more susceptible to early-onset hyperglycaemia, dyslipidaemia and hypertension ( $p$-values $\geq 0.05$ in all tests). 
Table 3. Association between features of the metabolic syndrome and polymorphic variants of the HSD11B1 gene analysed in 203 obese children and adolescents aged 10-18 years old

\begin{tabular}{|c|c|c|c|c|c|c|c|c|c|c|c|c|c|}
\hline \multirow{2}{*}{$\begin{array}{l}\text { SNP } \\
\text { Genotype }\end{array}$} & & \multicolumn{3}{|c|}{ rs4844880 } & \multicolumn{3}{|c|}{ rs846910 } & \multicolumn{3}{|c|}{ rs3753519 } & \multicolumn{3}{|c|}{ rs12086634 } \\
\hline & & TT & $\mathrm{TA}+\mathrm{AA}$ & $p$ & GG & $\mathrm{GA}+\mathrm{AA}$ & $p$ & GG & $\mathrm{GA}+\mathrm{AA}$ & $p$ & TT & $\mathrm{TG}+\mathrm{GG}$ & $p$ \\
\hline & $\mathrm{n}$ & 120 & 83 & & 171 & 32 & & 144 & 59 & & 114 & 89 & \\
\hline$W C<90^{\text {th }} p c$ & 54 & 33 & 21 & 0.727 & 45 & 9 & 0.832 & 37 & 17 & 0.648 & 26 & 28 & 0.166 \\
\hline$W C \geq 90^{\text {th }} p c$ & 149 & 87 & 62 & & 126 & 23 & & 107 & 42 & & 88 & 61 & \\
\hline $\mathrm{FPG}<5.6 \mathrm{mmol} / \mathrm{L}$ & 166 & 99 & 67 & 0.747 & 138 & 28 & 0.460 & 118 & 48 & 0.921 & 97 & 69 & 0.241 \\
\hline $\mathrm{FPG} \geq 5.6 \mathrm{~mol} / \mathrm{L}$ & 37 & 21 & 16 & & 33 & 4 & & 26 & 11 & & 17 & 20 & \\
\hline $\mathrm{HDL} \geq 1.03 \mathrm{mmol} / \mathrm{L}^{*}$ & 128 & 78 & 50 & 0.490 & 109 & 19 & 0.639 & 93 & 35 & 0.481 & 77 & 51 & 0.134 \\
\hline $\mathrm{HDL}<1.03 \mathrm{mmol} / \mathrm{L}$ & 75 & 42 & 33 & & 62 & 13 & & 51 & 24 & & 37 & 38 & \\
\hline $\mathrm{TG}<1.7 \mathrm{mmol} / \mathrm{L}$ & 152 & 94 & 58 & 0.172 & 131 & 21 & 0.187 & 113 & 39 & 0.065 & 90 & 62 & 0.130 \\
\hline $\mathrm{TG} \geq 1.7 \mathrm{mmol} / \mathrm{L}$ & 51 & 26 & 25 & & 40 & 11 & & 31 & 20 & & 24 & 27 & \\
\hline $\mathrm{BP}<130 / 85 \mathrm{~mm} \mathrm{Hg}$ & 158 & 91 & 67 & 0.410 & 136 & 22 & 0.178 & 114 & 44 & 0.475 & 88 & 70 & 0.804 \\
\hline $\mathrm{BP} \geq 130 / 85 \mathrm{~mm} \mathrm{Hg}$ & 45 & 29 & 16 & & 35 & 10 & & 30 & 15 & & 26 & 19 & \\
\hline
\end{tabular}

*In patients aged > 16 years old gender-related differences are considered, with cut-off value for males equal to 1.03 and for females 1.29 mmol/L. SNP — single nucleotide polymorphism; WC - waist circumference; Pc - percentile; FPG — fasting plasma glucose; HDL — high-density lipoprotein cholesterol; TG - triglyceride; $\mathrm{BP}$ - blood pressure

\section{Discussion}

Despite the former reports suggestive of an association between HSD11B1 polymorphisms and obesity and its related metabolic disorders, we could not confirm these findings in our study. Association of the HSD11B1 gene variants with MetS was reported in South Indians, whereas relationship with T2D was detected in Native Americans originating from Pima population [18, 31]. In Europeans, association with MetS was found in Italian women, while a small study in Bosnians revealed correlations with BP, HOMA-IR and LDL cholesterol values [15, 32]. Moreover, HSD11B1 gene appeared to influence glucose and HDL cholesterol level in Brazilian females of European descent [33]. Although data from adults do not confirm direct effect of HSD11B1 polymorphisms on body mass, an association with obesity and its measures (BMI, WC, waist-to-hip ratio) was reported in Spanish, American and Chinese children $[20,21,23]$. Results with regard to insulin and its action are contradictory in Spanish and Mexican-American youth [20, 22]. This latter cohort also revealed a relationship between HSD11B1 polymorphism and circulating triglycerides [22].

Although equally conducted among children and adolescents, our investigation failed to detect similar associations with the HSD11B1 gene variants. One possible explanation relies on population differences, which are commonly encountered in association studies, including those concerning obesity [34]. Lack of sufficient power is another reason that should be considered, given a limited number of participants and low frequency of the minor alleles in our population, ranging from $5.4 \%$ for $A$ at rs 846910 to $24.6 \%$ for $T$ at rs 12086634 . Therefore, assuming an OR of 1.5 , the current analysis presented 49.5 to $93.2 \%$ power to detect an effect of the investigated polymorphisms. Finally, the choice of the studied SNPs might also play a role. Their selection was based upon former data indicating plausible association with obesity, but we also paid attention to experimental evidence of their functionality. The minor $\mathrm{G}$ allele of rs 12086634 alone and in combination with rs 846910 was found to affect HSD11B1 gene transcriptional activity, whereas in vitro studies evaluating solely the functional aspect of rs846910 did not reveal differences in HSD11B1 expression and enzyme activity [14-16, 18]. Moreover, an inhibitory effect on gene transcription was detected for the minor A allele at rs4844880 [17]. However, in vitro assays usually focus on specific gene variants, which are analysed separately, hence their results may not be relevant for the situation in vivo, when effects of several polymorphism cumulate and overlap. Therefore, we cannot exclude that the HSD11B1 variants investigated in our study are of no functional significance. As a matter of fact, lack of association between HSD11B1 gene polymorphisms and metabolic complications of obesity was reported in adult populations of French Canadians, Japanese and elderly Dutch [24, 35, 36]. Still, other gene variants might be implicated in development of MetS traits. A recent Polish study demonstrated an association between HSD11B1 rs45487298 and essential hypertension in adults [37]. Moreover, within the hypertensive cohort this polymorphism appeared strong predictor of T2D and lower circulating HDL cholesterol, 
although these observations were not confirmed in the control group [37].

On the other hand, our previous analysis conducted in patients with primary adrenal failure who require lifelong glucocorticoid substitution, revealed that HSD11B1 rs3753519 was associated with BMI and fasting plasma glucose, whereas rs12086634 appeared associated with circulating cholesterol [38]. Analogous findings with regard to rs4844880, BMI and weight gain during glucocorticoid replacement were reported in a smaller Hungarian cohort of subjects with adrenocortical insufficiency [39]. These patients are usually treated with hydrocortisone, identical with the natural cortisol molecule, but its proper dosage, mimicking natural diurnal rhythm of cortisol secretion, remains a challenging issue. Differences in $11 \beta$-HSD1 activity may therefore enhance individual susceptibility to the adverse effects of inadvertent excess glucocorticoid supply. However, observations in this specific population constantly receiving exogenous steroids may not be relevant for obese patients, who rely on endogenous regulation of the HPA axis.

To summarize, our study does not corroborate the role of polymorphic variants of the HSD11B1 gene in obesity and other features of the metabolic syndrome. Nevertheless, there are consistent experimental and clinical data to support the implication of $11 \beta$-hydroxysteroid dehydrogenase type 1 in pathogenesis of obesity-related metabolic disease. However, enzyme activity may be influenced by factors other than genetic polymorphisms. Investigation of modulators of the glucocorticoid action in tissues seems to be justified and promising area to explore in obesity and obesity related metabolic disorders.

\section{Acknowledgements}

The study was supported by a research grant from the Polish Diabetes Society (awarded to M.F., 2013). We are grateful to the authorities and employees of the Regional Blood Transfusion Centre in Poznan for their invaluable help with control sample collection.

\section{Conflict of interests}

The authors declare no conflict of interests.

\section{REFERENCES}

1. Garanty-Bogacka B, Syrenicz M, Rać M et al. Association between serum osteocalcin, adiposity and metabolic risk in obese children and adolescents. Endokrynol Pol 2013; 64: 346-352.

2. Alberti KG., Zimmet P., Shaw J. Metabolic syndrome - a new world-wide definition. A Consensus Statement from the International Diabetes Federation. Diabet Med 2006; 23: 469-480.

3. Ferrau F, Karbonits M. Metabolic comorbidities in Cushing's syndrome. Eur J Endocrinol 2015; 173: M133-M157.
4. Pisarczyk-Wiza D, Zozulińska-Ziółkiewicz D. Glikokortykosteroidy a zaburzenia metabolizmu glukozy. Clin Diab 2015; 4: 110-116.

5. Incollingo Rodriguez AC, Epel ES, White ML et al. Hypothalamicpituitary-adrenal axis dysregulation and cortisol activity in obesity: A systematic review. Psychoneuroendocrinology 2015; 62: 301-318.

6. Tomlinson JW, Walker EA, Bujalska IJ et al. 11 beta-hydroxysteroid dehydrogenase type 1: a tissue-specific regulator of glucocorticoid response. Endocr Rev 2004; 25: 831-866.

7. Ricketts ML, Verhaeg JM, Bujalska I et al. Immunohistochemical localization of type 111 beta-hydroxysteroid dehydrogenase in human tissues. J Clin Endocrinol Metab 1998; 83: 1325-1335.

8. Masuzaki H, Peterson J, Shinyama $\mathrm{H}$ et al. A transgenic model of visceral obesity and the metabolic syndrome. Science 2001; 294: 2166-2170.

9. Kotelevtsev Y, Holmes MC, Burchell A et al. 11 beta-hydroxysteroid dehydrogenase type 1 knockout mice show attenuated glucocorticoid-inducible responses and resist hyperglycemia on obesity or stress. Proc Natl Acad Sci USA 1997; 94: 14924-14929.

10. Alberts $P$, Engblom L, Edling $N$ et al. Selective inhibition of 11 beta-hydroxysteroid dehydrogenase type 1 decreases blood glucose concentrations in hyperglycaemic mice. Diabetologia 2002; 45: 1528-1532.

11. Desbriere $R$, Vuaroqueaux $V, A$ chard $V$ et al. 11 beta-hydroxysteroid dehydrogenase type 1 mRNA is increased in both visceral and subcutaneous adipose tissue of obese patients. Obesity 2006; 14: 794-798

12. Michailidou Z, Jensen MD, Dumesic DA et al. Omental 11 beta-hydroxysteroid dehydrogenase 1 correlates with fat cell size independently of obesity. Obesity 2007; 15: 1155-1163.

13. Veilleux A, Rheaume C, Daris M et al. Omental adipose tissue type 1 11 beta-hydroxysteroid dehydrogenase oxoreductase activity, body fat distribution, and metabolic alterations in women. J Clin Endocrniol Metab 2009; 94: 3550-3557.

14. Draper N, Walker EA, Bujalska IJ et al. Mutations in the genes encoding 11 beta-hydroxysteroid dehydrogenase type 1 and hexose-6-phosphate dehydrogenase interact to cause cortisone reductase deficiency. Nat Genet 2003; 34: 434-439.

15. Gambinieri A, Tomassoni F, Munarini A et al. A combination of polymorphisms in HSD11B1 associates with in vivo 11 beta\}-HSD1 activity and metabolic syndrome in women with and without polycystic ovary syndrome. Eur J Endocrinol 2011; 165: 283-292.

16. Malavasi EL, Kelly V, Nath N et al. Functional effects of polymorphisms in the human gene encoding 11 beta-hydroxysteroid dehydrogenase type 1 (11 beta-HSD1): a sequence variant at the translation start of 11 beta-HSD1 alters enzyme levels. Endocrinology 2010; 151: 191-202.

17. Feldman K, Szappanos A, Butz H et al. The rs4844880 polymorphism in the promoter region of the HSD11B1 gene associates with bone mineral density in healthy and postmenopausal osteoporotic women. Steroids 2012; 77: 1345-1351.

18. Nair S, Lee YH, Lindsay RS et al. 11 beta-Hydroxysteroid dehydrogenase Type 1: genetic polymorphisms are associated with Type 2 diabetes in Pima Indians independently of obesity and expression in adipocyte and muscle. Diabetologia 2004; 47: 1088-1095.

19. Moon SS, Lee YS, Kim JG et al. Relationship of $11 \beta$-hydroxysteroid dehydrogenase type 1 and hexose-6-phosphate dehydrogenase gene polymorphisms with metabolic syndrome and type 2 diabetes. Endocr J 2011; 58: 949-959.

20. Olza J, Gil-Campos M, Leis R et al. A gene variant of $11 \beta$-hydroxysteroid dehydrogenase type 1 is associated with obesity in children. Int J Obes (Lond) 2012; 36: 1558-1563.

21. Gelertner-Yaniv L, Feng N, Sebring NG et al. Associations between a polymorphism in the 11 beta hydroxysteroid dehydrogenase type I gene and body composition. Int J Obes Relat Metab Disord 2003; 27: 983-986.

22. Duran-Gonzalez J, Ortiz I, Gonzales E et al. Association study of candidate gene polymorphisms and obesity in a young Mexican-American population from South Texas. Arch Med Res 2011; 42: $523-531$ 
23. Ruan LL, Xu J, Wang CL, Zou CC. Variants of $11 \beta$-hydroxysteroid dehydrogenase (HSD11B) gene type 1 and 2 in Chinese obese adolescents. J Endocrinol Invest 2014; 37: 565-573.

24. Smit P, Dekker MJ, de Jong FJ et al. Lack of Association of the 11 beta-hydroxysteroid dehydrogenase type 1 gene 83,557insA and hexose-6-phosphate dehydrogenase gene R453Q polymorphisms with body composition, adrenal androgen production, blood pressure, glucose metabolism, and dementia. J Clin Endocrinol Metab 2007; 92: 359-362.

25. Kulaga Z, Litwin M, Tkaczyk M et al. Polish 2010 growth references for school-aged children and adolescents. Eur J Pediatr 2011; 170: 599-609.

26. Cole TJ, Freeman JV, Preece MA. Body mass index reference curves for the UK, 1990. Arch Dis Child 1995; 73: 25-29.

27. Kułaga Z, Litwin M, Zajączkowska MM et al. Porównanie wartości obwodów talii i bioder dzieci i młodzieży polskiej w wieku 7-18 lat z wartościami referencyjnymi dla oceny ryzyka sercowo-naczyniowego - wyniki wstępne projektu badawczego OLAF (PL0080). Standardy Medyczne/Pediatria 2008; 5: 473-485 .

28. Kułaga Z, Litwin M, Gajda A et al. Rozkłady wartości ciśnienia krwi w populacji referencyjnej dzieci i młodzieży w wieku szkolnym. Standardy Medyczne/Pediatria 2010; 7: 100-111.

29. Zeitler P, Fu J, Tandon N et al. ISPAD Clinical Practice Consensus Guidelines 2014. Type 2 diabetes in the child and adolescent. Pediatr Diabetes 2014;15 (Suppl 20): 26-46.

30. Zimmet P, Alberti KG, Kaufman F et al. The metabolic syndrome in children and adolescents - an IDF consensus report. Pediatr Diabetes 2007; 8: 299-306.

31. Gandhi K, Adhikari P, Basu A, Achappa B. Association between a $11 \beta$-hydroxysteroid dehydrogenase type 1 gene polymorphism and metabolic syndrome in a South Indian population. Metab Syndr Relat Disord 2013; 11: 379-402.

32. Dujic T, Bego T, Milnar B et al. Association between 11 beta-hydroxysteroid dehydrogenase type 1 gene polymorphisms and metabolic syndrome in Bosnian population. Biochem Med (Zagreb) 2012; 22: 76-85.

33. Turek LV, Leite N, Rodrigues Souza RL et al. Gender-dependent association of HSD11B1 single nucleotide polymorphisms with glucose and HDL-C levels. Genet Mol Biol 2014; 37: 490-495.

34. Rosmond R. Association studies of genetic polymorphisms in central obesity: a critical review. Int J Obes Relat Metab Disord 2003; 27: 1141-1151.

35. Robitaille J, Brouillette C, Houde A et al. Molecular screening of the 11 beta-HSD1 gene in men characterized by the metabolic syndrome. Obes Res 2004; 12: 1570-1575.

36. Miyamoto $\mathrm{Y}$, Morisaki H, Yamanaka I et al. Association study of 11 beta-hydroxysteroid dehydrogenase type 1 gene polymorphisms and metabolic syndrome in urban Japanese cohort. Diabetes Res Clin Pract 2009; 85: 132-138.

37. Hejduk P, Sakowicz S, Pietrucha T. Association between ins4436A in $11 \beta$-hydroxysteroid dehydrogenase type 1 gene and essential hypertension in Polish population. Postepy Hig Med Dosw 2015; 69: 1245-1250.

38. Fichna M, Żurawek M, Gryczynska M et al. Polymorphic variants of the HSD11B1 gene may be involved in adverse metabolic effects of glucocorticoid replacement therapy in Addison's disease. Eur J Intern Med 2016; 85: 99-104.

39. Molnar A, Kovesdi A, Szucs N et al. Polymorphisms of the GR and HSD11B1 genes influence body mass index and weight gain during hormone replacement treatment in patients with Addison's disease. Clin Endocrinol (Oxf) 2016; 85: 180-188. 